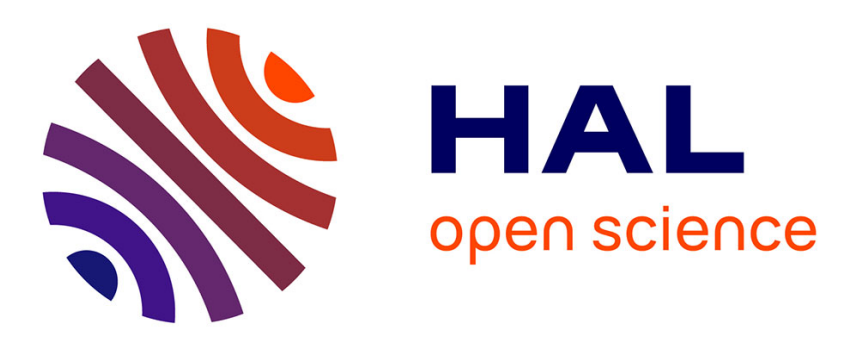

\title{
Whoring, Gaping and Hiding Meat: The Humour of Male-on-Male Sexual Insults in Aristophanes' Knights James Robson
}

\section{To cite this version:}

James Robson. Whoring, Gaping and Hiding Meat: The Humour of Male-on-Male Sexual Insults in Aristophanes' Knights. Archimède: archéologie et histoire ancienne, 2018, Archimède $n^{\circ} 5$. Archéologie et histoire ancienne, 5, pp.24-34. halshs-01825097

\section{HAL Id: halshs-01825097 https://shs.hal.science/halshs-01825097}

Submitted on 28 Jun 2018

HAL is a multi-disciplinary open access archive for the deposit and dissemination of scientific research documents, whether they are published or not. The documents may come from teaching and research institutions in France or abroad, or from public or private research centers.
L'archive ouverte pluridisciplinaire HAL, est destinée au dépôt et à la diffusion de documents scientifiques de niveau recherche, publiés ou non, émanant des établissements d'enseignement et de recherche français ou étrangers, des laboratoires publics ou privés. 


\section{ARCHIMÈDE N5

DOSSIER THÉMATIQUE : HUMOEROTICA

1 Ruby BLONDELL et Sandra BOEHRINGER

Humour et érotisme dans I'Antiquité grecque et romaine. Introduction au dossier

7 Marina HAWORTH

The Wolfish Lover: The Dog as a Comic Metaphor in Homoerotic Symposium Pottery

\section{James ROBSON}

Whoring, Gaping and Hiding Meat: The Humour of Male-on-Male Sexual Insults in Aristophanes' Knights

\section{Carmen DAMOUR}

De qui se moque-t-on? Les travestis sur la scène de l'Assemblée des femmes d'Aristophane

\section{Deborah KAMEN}

The Consequences of Laughter in Aeschines' Against Timarchos

57 Yvonne RösCH

Hunting Hares and Lovers: Socrates' Playful Lesson in Xenophon, Memorabilia III, 11

\section{Eugene 0'CONNOR}

Aroused by Laughter: Martial's Priapic Humor

83 Sandra BOEHRINGER with the artistic collaboration of Marjolaine FOURTON Not a Freak but a Jack-in-the-Box: Philaenis in Martial, Epigram VII, 67

\section{Michel BRIAND}

Des mœurs sexuelles des Sélénites (Lucien, Histoires vraies, I, 22) : entre satire queer et constructionnisme incarné, le sexe qui donne à rire et à penser

108 ACTUALITÉ DE LA RECHERCHE : DES FEMMES PUBLIQUES. GENRE, VISIBILITÉ ET SOCIABILITÉ DANS L'ANTIQUITÉ GRECQUE ET ROMAINE

185 VARIA

\section{LA CHRONIQUE D'ARCHIMÈDE}

\section{@creative (1) (1) ()}




\section{WHORING, GAPING AND HIDING MEAT: THE HUMOUR OF MALE-ON-MALE SEXUAL INSULTS IN ARISTOPHANES' KNIGHTS}

James ROBSON

Senior Lecturer in Classical Studies

Open University, UK

james.robson@open.ac.uk

\section{ABSTRACT}

This article looks at the obscene and scurrilous humour of Aristophanes' Knights with a view to examining how its main protagonists are characterized sexually. Through an examination of how the Sausage-Seller and Paphlagon are presented in terms of both sexual insertiveness and receptiveness - both anal and oral - I seek to challenge views of the play which cast Paphlagon as the more sexually aggressive of the two. Rather, the contention of the article is that the Sausage-Seller's aggression is expressed both through the direct nature of his sexual threats and the shameless ways in which

KEYWORDS

Aristophanes,

Knights,

obscenity,

humour,

jokes,

homoeroticism/"homosexuality",

penetration,

insertiveness,

receptiveness,

prostitution,

Henderson. he flaunts his whorishness and oral and anal receptiveness. In contrast, Paphlagon-Cleon's sexual character largely emerges through metaphors, allegations, innuendos and jokes made at his expense.
Cet article propose une étude de l'humour obscène et grossier des Cavaliers d'Aristophane et une analyse de la façon dont les personnages principaux sont caractérisés du point de vue de leurs pratiques sexuelles. En examinant la façon dont Aristophane présente le Marchand de saucisses et le Paphlagonien en termes de sexualité insertive et réceptive - à la fois anale et orale - je souhaite remettre en question l'interprétation de la pièce qui fait du Paphlagonien le personnage le plus agressif sexuellement des deux. Cet article montre en effet que l'agressivité du Marchand de saucisses est visible à la fois par le caractère direct de ses menaces sexuelles et l'indécence avec laquelle il exhibe son plaisir à vendre son corps et à se laisser pénétrer par I'anus et la bouche. Dans le cas du Paphlagonien/ Cléon, en revanche, le spectateur n'entrevoit sa dimension sexuelle qu'à travers des métaphores, des accusations, des sous-entendus et des plaisanteries faites à ses dépens.

Mots-cLÉs
Aristophane,
Cavaliers,
obscénité,
rire,
plaisanteries,
homoérotisme / « homosexualité »,
pénétration,
insertivité,
réceptivité,
prostitution,
Henderson.


If we are to believe the claims made by Aristophanes, Knights broke important new ground in the genre of Old Comedy when it was staged at the Lenaea in 424 BCE [1]. In the parabasis of Clouds (first produced the following year, 423 $\mathrm{BCE}$, but subsequently revised between 418 and 416 BCE), the chorus makes a series of assertions about the innovative nature of Knights, elements of which, they say - most prominently its sustained attack on a single political figure - have since been shamelessly copied by other comic playwrights such as Eupolis and Hermippus [2]. Whatever the status of these claims about originality and plagiarism, certainly Knights' relentlessly hostile focus on Paphlagon - a thinly veiled caricature of Cleon, Aristophanes' favourite comic target in the 420 s - is unique in our surviving plays [3]. Unappealing elements of this Paphlagonian slave's character continue to be revealed throughout the play, much of the action of which is taken up with a contest (or, rather, a series of contests) between PaphlagonCleon, the current "leader" of Athens, and a new pretender to this title, the Sausage-Seller [4]. The competition between the two men at times amounts to a struggle to prove which man is the better friend

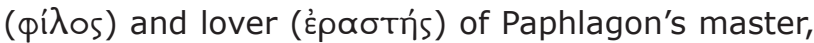
Demos (i.e. 'The People' of Athens) [5]. But at other times it is a race to the bottom [6], the conceit being that "the leadership of the people is no longer a job for an educated man or one of good qualities, but for one who's ignorant and foul" [7]. Knights is thus a play of pandering, wheedling and flattering on the part of Paphlagon and the Sausage-Seller as they vie to prove their dedication to Demos. But it is also a play of shameless deeds, scurrilous allegations and scandalous admissions, many of which involve the sexual realm.

A further unique feature of Knights is the maleon-male orientation of the play's sexual humour. This is a fact already noted by Henderson in his analysis of the obscene language of Knights in The Maculate Muse, where he suggests that the prevalence of "homosexual and scatological" obscenities is intimately connected to the "attack and exposure"
[1] Thanks are due to Sandra Boehringer and the two anonymous reviewers for their helpful corrections and insightful suggestions on an earlier draft of this paper.

[2] Aristophanes, Clouds, 553-559. Not that the pillorying of political figures was unknown in Old Comedy before $424 \mathrm{BCE}$, of course. Pericles was famously the butt of humour in a number of Cratinus' plays, for example, though his attacks plausibly took a somewhat different form from the sustained ad hominem attack on Cleon in Knights: see STOREY 2011a: 236.

[3] While claims to innovation and disparagement of rivals are something of a commonplace in Old Comedy (see, esp., WRIGHT 2012: 70-99), Aristophanes' centra point may well be valid here, namely that he innovated in making a single politician the central target of a play's attack. The first example of such a comedy by another poet seems to be Eupolis' Maricas (staged in 421 BCE: see STOREY 2011b: 148-151), which is singled out as derivative of Knights at Clouds, 554. As CASSIO 1985: 38, and STOREY 2011b: 150, both note, the surviving fragments of this play suggest various parallels with Knights, not least the casting of a politician, Hyperbolus, in the role of a foreign slave (cf. SoMMERSTEIN 1982, ad loc. on Clouds, 554). It is noteworthy that Eupolis appears to have responded to Aristophanes' allegations of plagiarism by claiming to have played a role in the composition of Knights (fr. 89), although this may simply amount to a counter-claim that Aristophanes plagiarized him (thus SOMMERSTEIN 1980: 51-53). On the rivalry between Aristophanes and Cleon, see LAFARgue 2013: 21-26.

[4] As outlined by BROCK 1986, who also articulates a number of the play's inconsistencies and paradoxes, e.g. discrepancies in the characterization of both the Sausage-Seller and Demos, and the "grand alliance" (21) between the base Sausage-Seller and the noble Knights.

[5] SCHOLtZ 2004 and YATES 2005. At Knights, 42, this character is explicitly referred to as "Demos of the Pnyx", i.e. "The People" of Athens as constituted as a political body at the city's Assembly.

[6] Or as Silk 2000: 336, puts it, an "extravagant exercise in competitive odiousness".

[7] Aristophanes, Knights: 191-192. Translations from Knights are those of SOMMERSTEIN 1981: the Greek text of his edition is also used throughout. 
of Paphlagon-Cleon (as well as the SausageSeller) [8]. Henderson further states that, when it comes to obscenity, Knights is almost devoid of what he terms "heterosexual language" since, unlike so many other Aristophanic plays, it fails to "celebrate peace and unfettered fertility" [9]. In contrast to "heterosexual" (i.e. heteroerotic) obscenity, then, which can be employed in Aristophanes' plays not only for the purposes of attack and deflation but also to promote a buoyant and celebratory mood, "homosexual" (i.e. homoerotic) obscenities find a narrower, characteristically "negative" set of uses [10]. And in Knights this includes adding an element of spice and bite to a number of the play's scurrilous jokes.

In this article I do not seek to challenge Henderson's basic premise that male-on-male obscenities - and the sexual humour they help to create - are overwhelmingly used with a hostile force in Knights: that much seems indisputable. Rather, I aim to examine a further claim of Henderson's, namely that while Paphlagon-Cleon is presented as someone who plays both the receptive and insertive role in male-on-male sex - "as both pathic and paedicator, the aggressor in homosexual contact" - the Sausage-Seller is presented as playing only the receptive role and as sexually unaggressive ("he is not an aggressor like Cleon; he is not a paedicator") [11]. Henderson's reading of the play is certainly engaging, casting as it does both men in the role of willing "bottoms" in the city, but Paphlagon alone - in his capacity as an aggressive "top" - in the role of a sexual and social manipulator. Yet we might note here that Henderson's reading unquestioningly equates anal insertiveness with both sexual assertiveness and political power and, furthermore, risks making Paphlagon the "winner" of a contest which he in fact loses [12]. Nor does Henderson's reading do full justice to the evidence, I suggest. For example, it relies heavily on what is arguably a tendentious interpretation of a short exchange between Paphlagon and the Sausage-Seller (Knights, 962-964), and also fails to take into account the fact that the Sausage-Seller, too, is capable of threatening his rival with anal penetration.

In the discussion that follows, I shall take a fresh look at the obscene and scurrilous humour of the play with a view to re-visiting the question of how its main protagonists are characterized sexually. In my analysis I will examine the ways in which the Sausage-Seller and Paphlagon are presented first in terms of sexual receptiveness (i.e. as penetrated), then in terms of sexual insertiveness (i.e. as penetrators) - both anally and orally - in a series of risqué jokes. To anticipate my conclusions, this discussion will indeed show differences in the ways in which Paphlagon and Sausage-Seller are aligned with sexual receptiveness and insertiveness. But the key distinction between the two rivals, I suggest, is that the Sausage-Seller is more prone to making outrageous threats and shameful admissions than his rival, whereas Paphlagon-Cleon's sexual character largely emerges through metaphors, allegations, innuendos and jokes made at his expense.

\section{THE PENETRATING HUMOUR OF KNIGHTS}

As has long been recognized, Knights forms part of a rich tradition of texts from Classical Athens that contain sexual insults aimed at politicians, portraying them as former prostitutes and/or as playing the receptive role in homoerotic sexual acts [13]. But in the comic world of Knights, where the two central figures compete in baseness, we find not just slurs against political opponents, but also frank admissions of wrongdoing - such as SausageSeller's open confession towards the end of the play to having prostituted himself in his youth.
[8] HENDERSON 1991: 67. For an overview of the uses of the nature and function of obscene expression in Aristophanes, see HENDERSON 1991: 30-107, and RoBSON 2009: 120-140.

[9] Ibid.

[10] Ibid. In this article I avoid using the terms "homosexual" and "heterosexual" (except in quotations) since, as many scholars have been at pains to point out, these are essentially modern categories which map poorly on to ancient conceptions of sexual behaviour: see, e.g. FOUCAULT 1985: 3-6 and 187-193, HALPERIN 1990: 1540, WinKLER 1990: 4, and WiLLiAMS 1999: 4-9.

[11] HENDERSON 1991: 68, followed by SCHOLTZ 2004: 264.
[12] Henderson is thus something of a "social constructionist" avant la lettre in the vein of HALPERIN 1990 and WINKLER 1990 (as, indeed, is DOVER 2016 [1978]: 100-109, "dominant and subordinate roles"). For a brief overview of social constructionism (with its "penetration = power" model) and its critics, see MASTERSON \& ROBSON 2016: 17-20.

[13] HeATH 1997: 232-233, usefully maps a fuller set of parallels between the "unpleasant characteristics" attributed to Paphlagon-Cleon in Knights and those ascribed to statesmen such as Demosthenes by their opponents in fourth-century oratory, which include sexual depravity. 


\section{Sommerstein translates:}

Paphlagon: When you were approaching manhood, what trade did you practise?

Sausage-Seller: I sold sausages ... and also

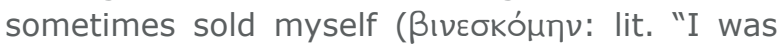
fucked"). [14]

This is hardly the first time in Knights that we have had hints of the Sausage-Seller's capacity for anal receptiveness, however. Most prominently, there is a lengthy humorous sequence earlier in the play where the Sausage-Seller reports some of his shameless youthful exploits.

Sausage-Seller: And, oh yeah, there are other pranks of mine, when I was a boy. I used to trick the butchers by saying this sort of thing: "Look, boys, don't you see? The new season; a swallow!" And they'd look up, and in the meantime I'd steal some of their meat (kpéas) ... And nobody saw me doing it. But if ever any of them did, I'd hide the

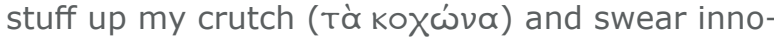
cence by the gods. So that one of the politicians said, when he saw me doing that, "It's certain as certain can be that this boy will one day hold the stewardship of the people".

Demosthenes: He guessed well. But it's obvious what led him to that conclusion: the fact that you perjured yourself after committing a robbery, and that you had someone's meat

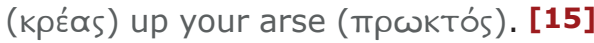

One of the noteworthy features of this passage is the way in which the slave, Demosthenes [16], immediately presents a potted summary of the joke, simultaneously extending the humorous moment (with the help, we note, of a climactic

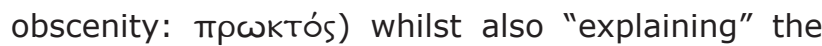
joke for anyone in the audience who failed to get it the first time. An indication of the joke's thematic importance in the play - and also, perhaps, of the fact that Aristophanes was particularly proud of it

[14] Knights, 1242-1243.

[15] Knights, 417-428.

[16] Neither slave is named in the text, but they are traditionally identified as Demosthenes and Nicias (see, e.g., Sommerstein 1981: 3).

[17] Thus SommerSTEIN 1981 ad loc.

[18] Knights, 719-720.

[19] Knights, 721.

[20] Cf. Paphlagon's "gaping" anus: see below.
- is that it is mentioned again just a few lines later (482-484).

A further joke that underscores the SausageSeller's anal receptiveness is his much-quoted retort to Paphlagon's boastful claim to have Demos/ The People of Athens in his sway. Using an otherwise unattested - but perhaps proverbial - expression [17], Paphlagon brags:

Paphlagon: And what is more, by Zeus, with my wizardry I can make Demos expand and contract at my pleasure. [18]

To which his adversary replies:

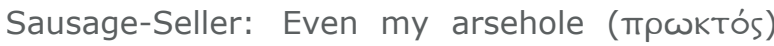
knows that trick. [19]

Anal receptiveness may not be explicit in this joke, but mention of the Sausage-Seller's anus is nevertheless suggestive, with the process of expansion and contraction plausibly evoking anal intercourse. Indeed, the line might even be understood as the vulgar boast of a male prostitute - a claim that, with the control he has over his sphincter muscle, he can more easily accommodate and all the better satisfy his clients [20].

One final joke to mention in connection with the Sausage-Seller's anal receptiveness comes from the prologue of the play. The slave, Demosthenes, has just hailed the Sausage-Seller as a new saviour

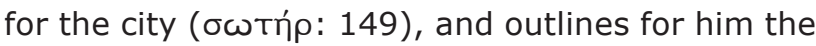
potential benefits that power will bring. At the end of the list, we find a typically Aristophanic example of humour relying on a surprise, obscene item.

Demosthenes: Do you see all the serried ranks of this assembled host? [meaning the audience]

Sausage-Seller: Yes.

Demosthenes: Of all these you shall be the paramount chief ( $\alpha \rho x \varepsilon \dot{\varepsilon} \lambda \varsigma_{\varsigma}$ ), chief too of the market, the harbours and the Pnyx. You'll trample on Council and trim back the generals; you'll chain,

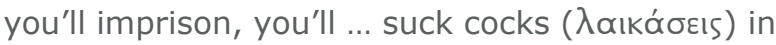
the Prytaneum.

(Knights, 163-167)

This joke once again links the Sausage-seller to receptive sexual acts - this time oral rather than anal. But, of course, these lines do not only serve to cast the Sausage-Seller as a potential fellator. Implicit here is the notion that the current "chief" of Athens, Paphlagon, engages in this practice, too. 
So much for the Sausage-Seller's oral and anal receptiveness: this would-be "leader" of Athens is a self-confessed prostitute who has previously hidden meat up his crutch, boasts about his ability to control his anal sphincter muscle and whose future leadership of Athens will potentially see him orally service Athens' Prytaneis. But what of Athens' current "leader"? Paphlagon may not confess to being sexually penetrated as openly as the Sausage-Seller, but he is nevertheless regularly associated with anal receptiveness. For instance, Paphlagon's "arse"

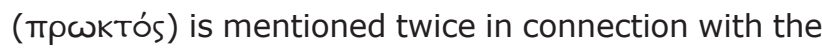
play's theme of "gaping" (a concept which evokes the open-mouthed gullibility of the common people of Athens as well as the propensity of the city's leaders to play the receptive role in anal sex) [21]. The first example of this comes at line 78 during Demosthenes' brief portrait of the mighty and all-seeing Paphlagon. Here a weak pun on "Chaonians" (a tribe living in the region of Epirus) is employed in order to evoke the idea of Xóos, "a gaping void" (cf. Xóokw, "to

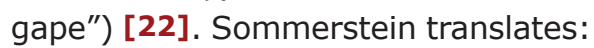

Demosthenes: But there's nothing can elude Paphlagon's eyes. That man watches over everything. He stands with one leg in Pylos and the other in the Assembly, with his feet this far

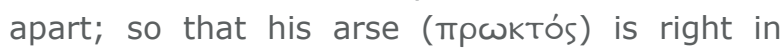
Chasmos ( $\dot{v} v$ Xóooıv), his hands in Extortia, and his mind in Larcenadae. [23]

The physical nature of this description, including the reference to Paphlagon's feet being "this far apart", would presumably have been accompanied by some stage business on the part of the actor playing Demosthenes, thus further underscoring the notion of Paphlagon's anal receptiveness and his chasm-like anus.
The references to gaping continue. Later in the play, Paphlagon is spoken of as a pig undergoing inspection - but rather than his open mouth, it is his "gaping" (КEXฑ́votos) anus that Demosthenes imagines examining.

Demosthenes: And, by Zeus, we'll shove a peg in his mouth as the butchers do, then pull out his tongue and take a good and proper look at him,

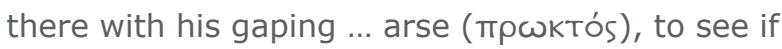
he's measly. [24]

A further joke at $876-880$ sees Paphlagon boast-

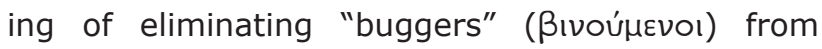
Athens' citizen rolls - an act that the SausageSeller immediately characterizes as "arse snooping"

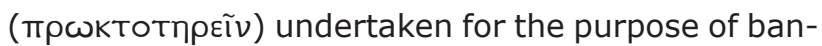
ishing future rivals. The conceit here - namely that the city's leaders are characteristically drawn from the ranks of those who have a history of anal receptiveness (either as prostitutes and/or as erōmenoi) - would further suggest, of course, that Paphlagon, too, is a "bugger".

Here we are once again in the realm of jokes made at Paphlagon's expense, but there is also at least one moment in the play where Paphlagon might be said to characterize himself as a prostitute. When emphasizing his good service to the city in a prayer to Athena which opens the "Assembly" section of the rivals' competition, Paphlagon aligns himself not just with the dead politician and general Lysicles, but also with two of Athens' most famous courtesans [25].

Paphlagon: I pray to our Lady Athena, sovereign of the city, that if I have been the worthiest of all servants of the Athenian people (next to Lysicles, Cynna and Salabaccho) ... [26]
[21] Both senses are no doubt drawn on at Knights: 1262-1263, where Sausage-Seller tells Demos that "you will agree you've never seen a man who was a better friend than me to the city of the ... Open-Mouthenians

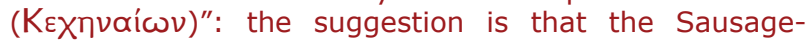
Seller's "gaping" arse demonstrates his solidarity with the "open-mouthed" Athenians. See also WoHL 2002: 80-92 and WORMAN 2015, who discusses the ways in which "sex at the ass end, talk and the feminine" (225) regularly coalesce both in Old Comic abuse and in the negative characterization of individuals in oratory. Crucially, WORMAN 2015 sees male-on-male sexual insults aimed at political figures primarily as metaphors "invoked to mock pandering, among other things, in male arenas such as the Assembly and the Prytaneum".

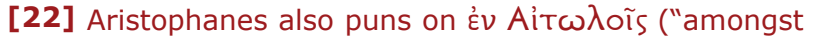
the Aetolians"), cf. ๔iт $\varepsilon^{\prime} \omega$, "ask for, demand, beg", and ḱv
K $\lambda \omega \pi เ \delta \tilde{\omega} \nu$ ("in Clopidae": a small settlement in Attica), cf. $k \lambda \omega \psi$, "thief". See also Rosen 1988: 66.

[23] Knights, 74-79.

[24] Knights, 375-381.

[25] Cynna (Kúvva) is a name used elsewhere by Aristophanes to refer to Cleon (Wasps, $1032=$ Peace, 755). While possibly conjuring up the politician's own name $(K \lambda \varepsilon \dot{\varepsilon} \omega \nu)$, it also plays on Cleon's self-definition as "watchdog of the people" (Kúwv, "dog": cf. Wasps, 8931008 ) as well as evoking the Dog Star with its supposedly harmful rays (see SOMMERSTEIN 1983 on Wasps: 1032 ad loc. and Austin \& OLSON 2004 on Peace, 755 ad loc.). Salabaccho's name is also mentioned at Thesmophoriazusae: 805 , where she is briefly compared to the politician Cleophon.

[26] Knights, 763-765. 
These lines hardly amount to a direct admission of involvement in prostitution to rival that of the Sausage-Seller, however. Rather, what we have here is an example of an Aristophanic joke technique whereby characters undercut or incriminate themselves in something resembling a comic aside [27]. In short, while Paphlagon is regularly associated with anal receptiveness (as well as a "gaping" mрwктós), this is done through a series of jokes, smears and a casual aside. When it comes to brazen admissions of anal (and oral) receptiveness, the Sausage-Seller beats Paphlagon hands down [28].

But what about Paphlagon as penetrator as well as penetrated? Henderson's reading of the play puts Paphlagon's capacity for aggressive, sexual penetration at its heart, equating it with his domination of Athens; or put simply, Paphlagon is "an oppressor (bugger) of the people" [29] (compare the seemingly domineering, ithyphallic individual in fig.1). Certainly there is plenty of material in the play to support the idea of Paphlagon as a domineering force who harasses his political opponents, subjugates Demos and keeps the people of Athens under his thumb [30]. But, importantly, when it comes to anal sex, there are at best a handful of places where Paphlagon is clearly cast in an insertive role [31].

At the heart of Henderson's analysis is his reading of a brief exchange between Paphlagon and the Sausage-Seller. This comes at the point in the play when the two are about to cite oracles in support of their respective claims to be Athens' rightful leader - as a prelude to which, each man warns Demos of the consequences of trusting the other.

Paphlagon: Huh! If you believe him, you're des-

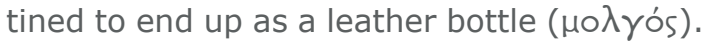

Sausage-Seller: And if you believe him, you're destined to end up with a cock skinned back to

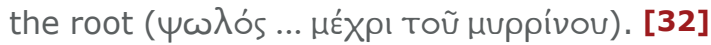

What do these references to a "leather bottle" and foreskinless penis ( $\psi \omega \lambda$ ós) signify? Unlike Henderson, the play's most recent commentator, Sommerstein, does not appear to see any

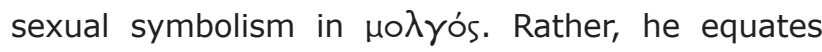
the leather bottle with being "flayed alive" (a punishment that a tanner such as Paphlagon-Cleon is well positioned to inflict, of course), while also detecting (most appropriately, given the context) "an allusion to two famous oracles (Plutarch, Life of Theseus 24.5) comparing Athens to a skin bottle floating in the sea" - an allusion which appears to

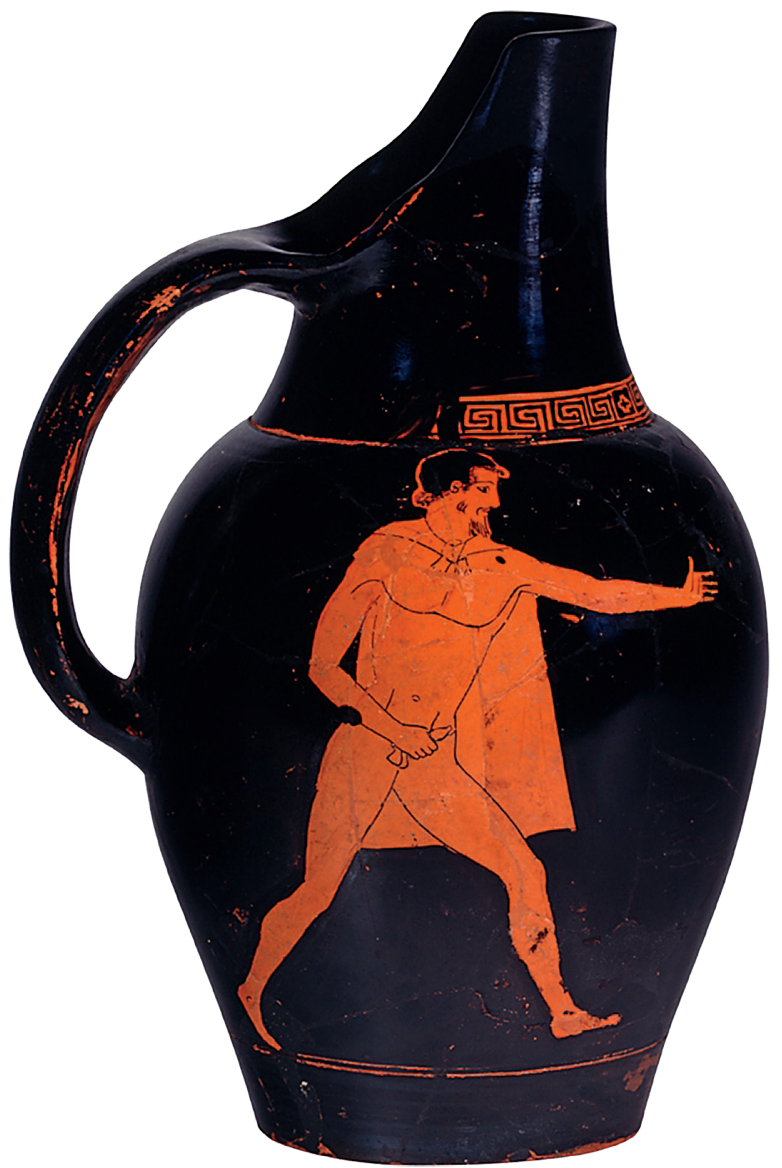

Figure 1

The Eurymedon vase: a red-figure oenochoe, attributed to the circle of the Triptolemos painter; Attica, c.460 BCE. An man, naked except for a short cloak, holds his erect penis in his right hand and approaches a Persian archer who is bent at the hips and looks out towards the viewer. The wording

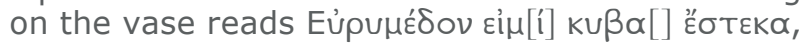
'I am Eurymedon, I stand bent over'.

Museum für Kunst und Gewerbe, Hamburg. $\mathrm{N}^{\circ}$ inv. 1981.173 (public domain).

[27] DOVER 1973: 59-60.

[28] Or as Henderson 1991: 68, puts it: "whereas Cleon never admits the vice of which the other characters accuse him, the Sausage-Seller proudly proclaims it". It is noteworthy, too, that at the end of the play, Paphlagon is banished to the city gates of Athens, where he is destined to "exchange foul language with the prostitutes" (Knights, 1400).

[29] HENDERSON 1991: 68.

[30] Though, of course, as a panderer Cleon subjugates himself to Demos, too. The very first account that Demosthenes gives of Paphlagon in the prologue (Knights, 43-72) provides a programmatic summary of a number of his character traits: here we learn that he fawns over his master, takes credit for gifts to Demos that other men have prepared, and makes false accusations and threats against his fellow slaves.

[31] Notwithstanding the fact that Cleon (and the Sausage-Seller) are also cast in the roles of anterastai: see Conclusions (below).

[32] Knights, 962-964. 
recur in three further Aristophanic fragments, too (frs 103 KA (Farmers), 308 KA (Heroes), and 933 KA (Dubia) [33]. As for $\psi \omega \lambda$ ós, this is an obscene word denoting a penis with a retracted foreskin, thus indicating either an erect or circumcised male member [34]. Sommerstein understands $\psi \omega \lambda$ ós in the second sense here - "a cock skinned back to the root", glossing the phrase as "an exaggerated expression for 'circumcised', this being regarded ... here ... [as] a fate worth than death" [35]. But why should Aristophanes make a connection between Paphlagon and circumcision? Sommerstein offers no explanation, but an answer can be found easily enough, I think. It is a something of a commonplace of political rhetoric in Classical Athens to allege that rivals are of foreign descent [36]. And since circumcision is a characteristically barbarian practice, this reference could therefore plausibly be said to spring from Paphlagon-Cleon's characterization as a foreigner in Knights: a Paphlagonian slave who has usurped citizen status.

Henderson has a different take on these lines. For him, Demos is being warned by each man not to emulate his opponent in case he should come to resemble him both sexually and politically. In the case of the Sausage-Seller this would entail him

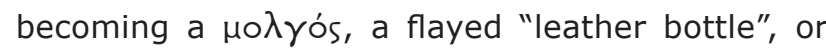
as Henderson understands this "well-worn anally", i.e. sexually penetrated and, by analogy, politically subjugated [37]. But in the case of Paphlagon, the risk is the opposite, namely that Demos would become an extreme version of a $\psi \omega \lambda \lambda_{\text {s, }}$ "a totally aggressive pederast, all hard-on", i.e. sexually and politically domineering. Henderson's understanding of the exchange is ingenious, to be sure, but it also raises a number of questions, not least whether there is enough differentiation elsewhere in the play between Paphlagon as penetrator and Sausage-Seller as penetrated for this reading to be compelling [38]. And, there is the question, too, as to whether audience members would have caught the allusion to anal penetration in what is a fast moving scene [39]. Certainly, we are a far cry from the repetition and reinforcement of the "hiding the meat" joke that we saw earlier. If Henderson is right the contrast between the Sausage-Seller as an anally receptive $\mu \circ \lambda \gamma$ ós and Paphlagon as a sexually insertive $\psi \omega \lambda{ }^{\prime}$ s is thematically important in Knights, it is an allusion that not all of Aristophanes' audience may have grasped from this exchange.

The only other line in the play that Henderson seems to adduce to support the idea of Paphlagon "violating his victims sexually" is Knights 263 [40]. This comes at the end of a passage in which the chorus alleges that Paphlagon uses heavy handed tactics to extort money from individuals. They say to him [41]:

Chorus: ... you eat up the public funds before the lot has fallen on you, and pick off the outgoing

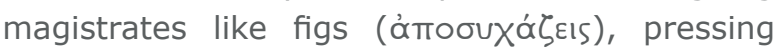
( $\left.\pi \varepsilon^{\zeta} \zeta \omega \nu\right)$ them to see which of them is green or ripe or not yet ripe. Yes, and you seek out any private citizen who's a silly lamb, rich and not wicked and frightened of public affairs, and if
[33] As SOMMERSTEIN 1981 points out, in each of these fragments (as in Knights), Aristophanes also chooses the

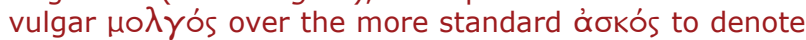
the bottle.

[34] Instructively, HENDERSON 1991: 110, seems to be of the view that $\psi \omega \lambda \eta^{\prime} / \psi \omega \lambda$ ós and cognates routinely indicate sexual arousal (rather than circumcision). Cf. Sommerstein 1987 and Dunbar 1995 on Birds, 507 ad loc. (an admittedly challenging passage, however, comprising a series of complex puns). At Wealth, 267, it certainly seems unlikely that Ploutos is being described as sexually aroused (on which see SoMMERSTEIN 2001 ad loc.).

[35] SOMMERSTEIN 1981.

[36] See, e.g. HEATH 1997: 232-3.

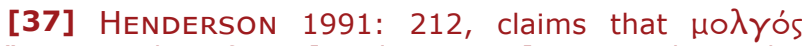
"was a Schimpfwort [insulting term] in comedy similar to katamú $\gamma \omega v^{\prime \prime}$ which, as he points out (212, n.

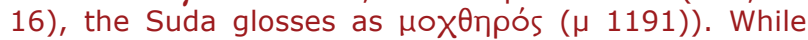
I would suggest that neither of the passages he cites

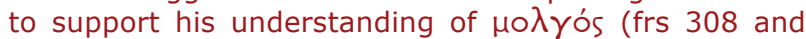
$933 \mathrm{KA}$ ) requires the word to be read in this light, a sexual meaning is admittedly possible. Henderson's interpretation of $\mu \mathrm{o} \lambda \gamma$ ós is explicitly supported by SCHOLTZ 2004: 273, n. 33.

[38] Indeed, playing devil's advocate - while still reading these lines in a sexual light - one could also challenge the whole basis of Henderson's logic here, i.e. that Demos is being warned by each man not to emulate his opponent. If each man is instead thought of as warning of the consequences of his opponent's victory, then it is the Sausage-Seller who will potentially turn Demos into a $\mu \mathrm{o} \lambda \gamma$ ós (by penetrating him) and Paphlagon who will turn him into a $\psi \omega \lambda$ ós (by demanding constant penetration).

[39] And also, indeed, whether they would have readily made an equation between these sexual acts and notions of social and political domination and submission. There is, admittedly, always the possibility that stage action was used to bring out some or all of the resonances that Henderson suggests.

[40] HENDERSON 1991: 68.

[41] On the allusion to a citizen living in the Chersonese, see SOMMERSTEIN 1981 ad loc., whose best guess is that Aristophanes has in mind a "merchant, perhaps in the corn trade". 
you discover one of [the citizens] who's a simple (КEXワvóta: lit. "open-mouthed, gaping") fellow minding his own business, you bring him home from the Chersonese, take him round the waist with slanders, hook his leg, then twist back his shoulder and plant your foot on him. [42]

Presumably, Henderson's reading of these lines is largely built on the sexual metaphors involving "figs" and "pressing" which are to be found at the beginning of this choral ode, i.e. the accusation that Paphlagon picks off public officials like figs

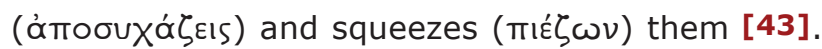
Indeed, Knights, 258-260 can be seen as lending support to Henderson's view of Paphlagon as a sexual aggressor of sorts, since he is arguably being portrayed here - albeit, we note, in metaphorical language - as a man who intimidates public officials sexually and exploits them financially. Whether Henderson is right to read the wrestling imagery at Knights 263 in a sexual light is perhaps more of a moot point, however. To be sure, wrestling and sexually imagery are intertwined elsewhere in Aristophanes - in heteroerotic contexts, at least, such as Acharnians, 271-275 (where Dicaeopolis imagines sexually assaulting the slave-girl, Thratta) and Peace, 894-898 (where Theoria is envisaged as being wrestled and used as a sexual plaything by the city's Council) [44], but at the end of this passage Aristophanes does not appear to be presenting Paphlagon as someone whose physical bullying extends to sexual assault [45].

A further significant passage of Knights when it comes to Paphlagon's sexual characterization - one that Henderson curiously overlooks - comes from a feisty exchange earlier in the play. Paphlagon, who has just been deriding the Sausage-Seller's oratorical abilities, goes on to stake his own claim to oratorical prowess. This involves boasting about

[42] Knights, 259-263.

[43] On ámoouxá $\zeta \omega$ as a sexual metaphor, see TAILLARDAT 1965: 76, and HENDERSON 1991: 117-118.

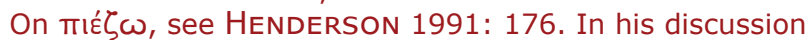
of these lines, Rosen 1988: 68, takes the view that there is "little doubt that the poet's intention was to elicit admiration for his clever obscenity rather than serious outrage at Cleon in particular."

[44] See García Romero 1995, esp. : 67-73, and ROBSON 2015: 317-322.

[45] Wrestling imagery is used (in a non-sexual way) elsewhere in the play, too, e.g. Knights, 387-388 and 490-492.

[46] Knights, 353-355.

[47] While this verb may have been in common usage, his ability to gain influence over his enemies even after engaging in gluttony and drunkenness. In the course of this boast, he uses the unusual verb к $\sigma \alpha \lambda \beta \alpha \dot{\alpha} \zeta \omega$. Sommerstein translates:

Paphlagon: Do you compare any man alive to me? I'll swallow down hot slices of tunny, and then drink a jugful of neat wine to follow, and straight

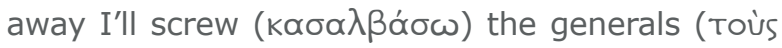
... отратпүoús) at Pylos. [46]

Quite what $k \propto \sigma \alpha \lambda \beta \alpha \dot{\alpha} \zeta \omega$ signifies is not straightforward to determine - and, indeed, may not have been immediately clear to Aristophanes' audience, either [47]. It is cognate with nouns

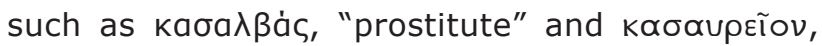
"brothel" [48], the only other occurrence of this verb coming in a fragment of the comic poet Hermippus (iambic fr. 5) [49] where it seems simply to evoke the idea of "acting like a prostitute" - or as LS] [50] quaintly puts it "behave like a strumpet". So might the use of this verb in Knights similarly suggest whorish behaviour on the part of Paphlagon: that is to say, sexual licentiousness to match the extraordinary greed and over-indulgence that he brags about in respect of food and wine? [51] Maybe. But this reading does present some challenges. First, is the problem of accommodating the accusative, toùs ... oтpatnyoús ("behave whorishly in respect of the generals"?). And second, is that the context demands the added idea of gaining influence or control (perhaps possible if, by "behaving whorishly", Paphlagon is to be thought of as having the generals in his thrall, e.g. as satisfied or infatuated clients?). But there is also an alternative way to understand this verb. LS] suggests a separate meaning for Knights, 355 which accommodates

its scarcity in surviving literature (only two occurrences; both in comedy) suggests otherwise and plausibly marks it out as a comic coinage. The fact that LSJ provides two competing definitions for $\kappa \alpha \sigma \alpha \lambda \beta \alpha \dot{\zeta} \omega$ (one for each occurrence) might further imply that its meaning is malleable and/or not wholly fixed.

[48] Thus providing a further association between Paphlagon and prostitution (on which see WOHL 2002: 90). See also HENDERSON 1991: 212-213, who suggests a possible connection between these cognates and kđoñs, "skin" or "hide" (cf. Latin scortum).

[49] Quoted by the scholiast to Aristophanes, Wasps, 1164.

[50] LIDDELL \& SCOTT 1996.

[51] NeIL 1901 ad loc. comments that the quantities of food and drink mentioned are "Gargantuan". 
the use of a direct object with the verb - the equally quaint "abuse ... in strumpet fashion" which renders a sense closer to Sommerstein's "screw" ("treat the generals like whores"?) [52]. If LS] is right, then we can finally lay claim to an instance of Paphlagon boasting about his capacity to act as a sexual penetrator [53].

So much for Paphlagon-Cleon as a sexual penetrator: what about his rival? The Sausage-Seller is characterized as an anal penetrator less than Paphlagon, to be sure, but there is nevertheless one clear and unambiguous penetrative threat that he makes. This comes in the midst of a vibrant passage of "combative capping" and draws on language appropriate to his profession in order to add a splash of comic colour [54].

Paphlagon: I'll leap on the Council and give it a violent shaking.

Sausage-Seller: And I'll stuff (ßuvńow) your arse

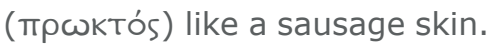

Paphlagon: And I'll drag you out of doors by the

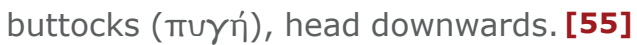

Characteristically of such passages in Knights, mutual threats continue to be exchanged between the two, with Paphlagon-Cleon at one point adopting metaphors taken from his realm of expertise: tanning and leather working. Whilst there are no further direct threats of penetration, some of the men's lines can nevertheless be read with a sexual subtext [56].

Paphlagon: Your hide will be stretched in the tanning-bench.

Sausage-Seller: I'll flay you into a thief's hold-all. Paphlagon: You'll be spread out and pegged to the ground.

[52] Sommerstein 1981 ad loc. Sommerstein makes it clear in his commentary how he has understood the verb: "English too can use this sexual metaphor as an alternative to others such as 'overwhelm' or 'put to flight'". WOHL 2002: 90, ingeniously combines the two meanings of the verb offered by LSJ when she suggests that Paphlagon "abuses the generals at Pylos by calling out to them like a prostitute calling for customers". In this, she is apparently following the lead of RoGERS 1910: 51, whose curious translation of Knights, 355, has Paphlagon "... with scurrilous abuse the Pylian generals smutch [i.e. "smudge"]".

[53] Bound up in this image may also be the idea that Cleon was the only "man" capable of resolving the Pylos issue, in contrast to the other generals who emerged from the episode as impotent subordinates to be equated
Sausage-Seller: I'll make mincemeat of out you... (Knights, 369-372)

What is noteworthy in this exchange is that Paphlagon-Cleon expresses himself in metaphorical language (which the Sausage-Seller then adopts, too, eventually steering the discourse away from metaphors taken from tanning and towards those based on his own profession of sausage making). But significantly, Paphlagon makes no direct sexual threat to match that of his rival.

There is one further example in the play of the Sausage-Seller using obscenity to underscore the notion of Paphlagon's penetration. Soon after the two protagonists have emerged with their respective collections of oracles, the Sausage-Seller hurls a devastating aside at his adversary, instructing him to self-fellate.

Sausage-Seller: He can go suck himself! (Tò méos oútooi Sớkol, lit. 'Let this man here bite his (?)

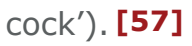

Here again the Sausage-Seller conjures up the notion of Paphlagon being penetrated - this time orally - and does so using wholly non-euphemistic language.

\section{CONCLUSIONS}

While the discussion in this article has focused on direct sexual references in Knights, much more can be said about the erotics of the play, of course. After all, one of the central conceits that helps to frame the action of Knights is the idea of orators as competing lovers (anterastai) of Demos/The People [58], a fascinating dynamic that has been

with "whores". However this line is to be understood, it is noteworthy both that it seems to carry the idea of gaining and/or displaying power over one's enemies and that this is expressed in sexual terms.

[54] On "combative capping" in Knights, see HESK 2007: 141-150.

[55] Knights, 363-365.

[56] HESK 2007: 148, certainly reads Paphlagon's lines in a sexual light, stating that in this passage "Cleon is more than happy to adopt the role of a homosexual rapist in his zeal to cap the threats of his opponent."

[57] Knights, 1010.

[58] A notion which is articulated most clearly at Knights, 732-736. 
productively explored by Yates and Scholtz [59]. Significantly for the current discussion, Scholtz sees as implicit in the notion of Paphlagon and the Sausage-Seller as erastai (i.e. "admirers" or "lovers") of Demos the idea that they are also both his "would-be 'buggerers'" [60] - which in turn serves as an important reminder that the erotic identities of the characters in Knights are shaped by more than the obscene and scurrilous jokes that have formed the basis of the present discussion [61].

But to return once more to those scurrilous jokes, what this brief study of Knights reveals is that, while Sausage-Seller and Paphlagon-Cleon are both characterized as engaging in receptive (as well as insertive) anal sex, there is an instructive distinction between the ways in which the sexual excesses of the two men are revealed. Paphlagon's sexuality is largely exposed in a series of smears, allegations and jokes made at his expense and is frequently couched in metaphorical language. In contrast, the Sausage-Seller openly declares his past as a prostitute, tells anecdotes at his own expense and boldly threatens his rival with sexual penetration. Importantly, it is not just the Sausage-Seller's penetrative threats that are more direct than those of his rival: he actively - even "aggressively" one might say - flaunts his whorishness and anal receptiveness. As befits the man who will be the ultimate winner of what is, in large part, a contest of baseness, the Sausage-Seller is simply the more outrageous and shameless of the two. He is not only an aggressive "top" but also an assertive and outspoken "bottom".

The Sausage-Seller's brazenness ultimately justifies his victory, but it also has interesting implications for how we might regard the two men.
In short, Paphlagon emerges as the more restrained and less brazen of the two - albeit in the context of a competition where all manner of shamelessness is revealed. But while the potential to view PaphlagonCleon as the lesser of two evils could potentially be considered a weakness in the design of Knights, there are nonetheless clear pay-offs to the way in which Aristophanes has plotted his play. The Sausage-Seller is a creation that allows Aristophanes to expose Paphlagon's excesses on the one hand and to magnify them on the other, by representing in an exaggerated, comic form the extreme behaviours of which politicians in general, and Cleon in particular, are allegedly capable. A further benefit, of course, is that the Sausage-Seller's success in outdoing his rival in baseness allows for the dramatically satisfying defeat of Paphlagon at the end of the play and his subsequent banishment to the city gates to ply his rival's lowly trade [62].

[59] SCHOLTZ 2004 and YATES 2005; see also LANDFESTER 1967: 50-60. Scholtz's discussion of the play is particularly useful in exposing a number of tensions inherent in the conceit of the political rivals' erotic-cum-pederastic courtship of Demos, and skilfully explores the cultural context of this theme as well as its consequences for how we read the play. $\mathrm{He}$ is, however, perhaps reductive when he claims that "[p]ederasty presupposes an erômenos (beloved) subordinate to his erastês (lover)" (ScHOLTz 2004: 274; cf. 277-278 where his discussion of erōs is more nuanced). See also VilLACÈQUe 2013: 241-243.

[60] SCHOLTZ 2004: 265; an idea repeated at 280 and 287.

[61] The character of Demos is of particular interest in this regard: cast in the role an erōmenos, an object of erotic pursuit, for most of Knights, at the end of the play his rejuvenation sees him enjoy the attentions of both a sexually available boy and the beautiful Spondai (Knights, 1384-1386, and 1390-1395).

[62] Knights, 1397-1399. 
Austin, Colin \& Olson, S. Douglas, 2004, Aristophanes Thesmophoriazusae, Oxford. Brock, Roger, 1986, «The Double Plot in Aristophanes' Knights », Greek Roman \& Byzantine Studies 27, p. 15-27.

CAssio, Albio Cesare, 1985, « Old Persian Marīka-, Eupolis Marikas and Aristophanes Knights », Classical Quarterly 35, p. 38-42.

Dover, Kenneth, 1972, Aristophanic Comedy, Berkeley.

Dover, Kenneth, 2016, Greek Homosexuality, $3^{\text {rd }}$ ed. ( $1^{\text {st }}$ ed. 1978), London - New York [tr. fr. Suzanne Saïd, Homosexualité grecque, Grenoble, 1982].

Dunbar, Nan, 1995, Aristophanes Birds, Oxford.

FoucAult, Michel, 1985, The History of Sexuality 2: The Use of Pleasure, [transl. eng. R. Hurley, New York] = L'Usage des plaisirs, Histoire de la sexualité, t. 2, Paris, 1984.

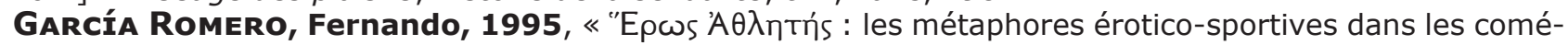
dies d'Aristophane », Nikophoros 8, p. 57-76.

Halperin, David, 1990, One Hundred Years of Homosexuality: And Other Essays on Greek Love, New York - London [tr. fr. Isabelle Châtelet, Cent ans d'homosexualité et autres essais sur l'amour grec, Paris, 2000]

HeAth, Malcolm, 1997, « Aristophanes and the Discourse of Politics », in Gregory Dobrov (ed.), Society and Representation in Athenian Drama, Chapel Hill - London, p. 230-249.

Henderson, Jeffrey, 1991, The Maculate Muse: Obscene Language in Attic Comedy, $2^{\text {nd }}$ ed. (1 $1^{\text {st }}$ ed. 1975), New York - Oxford.

Hesk, John, 2007, « Combative Capping in Aristophanic Comedy », Cambridge Classical Journal 53, p. 124-160.

LAfargue, Philippe, 2013, Cléon: le guerrier d'Athéna, Bordeaux.

LANDFESTER, Manfred, 1967, Die Ritter des Aristophanes, Amsterdam.

MASTerson, Mark \& Robson, James, 2016, « The Book and its Influence », preface to the $3^{\text {rd }}$ edition of DoVER, Kenneth, Greek Homosexuality (1 ${ }^{\text {st }}$ ed. 1978), London - New York, p. XV-XXVII.

NeIL, Robert Alexander, 1901, The Knights of Aristophanes, Cambridge.

RoBSON, James, 2009, Aristophanes: An Introduction, London.

Robson, James, 2015, « Fantastic Sex: Fantasies of Sexual Assault in Aristophanes », in Mark Masterson, Nancy Sorkin Rabinowitz, \& James Robson (ed.), Sex in Antiquity: Reconsidering Gender and Sexuality in the Ancient World, London - New York, p. 315-331.

Rogers, Benjamin Bickley, 1910, The Knights of Aristophanes, London.

Rosen, Ralph, 1988, Old Comedy and the Iambographic Tradition, Atlanta.

ScholTz, Andrew, 2004, « Friends, Lovers, Flatterers: Demophilic Courtship in Aristophanes' Knights », Transactions of the American Philological Association 134.2, p. 263-293.

SILK, Michael, 2000, Aristophanes and the Definition of Comedy, Oxford.

SOMmerSTeIN, Alan, 1980 « Notes on Aristophanes' Knights», Classical Quarterly 30.1, p. 46-56.

SOMmerSTeIn, Alan, 1981, The Comedies of Aristophanes vol. 2: Knights, Warminster.

Sommerstern, Alan, 1982, The Comedies of Aristophanes vol. 3: Clouds, Warminster.

SOMMERSTEIN, Alan, 1987, The Comedies of Aristophanes vol. 6: Birds, Warminster.

SOMmerstern, Alan, 2001, The Comedies of Aristophanes vol. 11: Wealth, Warminster.

StoreY, Ian, 2011a, Fragments of Old Comedy vol. I: Alcaeus to Diocles, Cambridge, Massachusetts - London.

Storey, Ian, 2011b, Fragments of Old Comedy vol. II: Diopeithes to Pherecrates, Cambridge, Massachusetts - London.

TAILlaRdAT, Jean, 1965, Les images d'Aristophane : études de langue et de style, Paris.

VIllacèque, Noémie, 2013, Spectateurs de paroles! Délibération démocratique et théâtre à Athènes à l'époque classique, Rennes.

Wrlliams, Craig, 1999, Roman Homosexuality, Oxford.

WinkleR, John, 1990, The Constraints of Desire: The Anthropology of Sex and Gender in Ancient Greece, London - New York [tr. fr. Sandra Boehringer \& Nadine Picard, Désir et contraintes en Grèce ancienne, Paris, 2005].

WонL, Victoria, 2002, Love Among the Ruins: The Erotics of Democracy in Classical Athens, Princeton. WrIGHT, Matthew, 2012, The Comedian as Critic: Greek Old Comedy and Poetics, London.

YATES, Velvet, 2005, «Anterastai: Competition in Eros and Politics in Classical Athens », Arethusa 38.1, p. 33-47. 